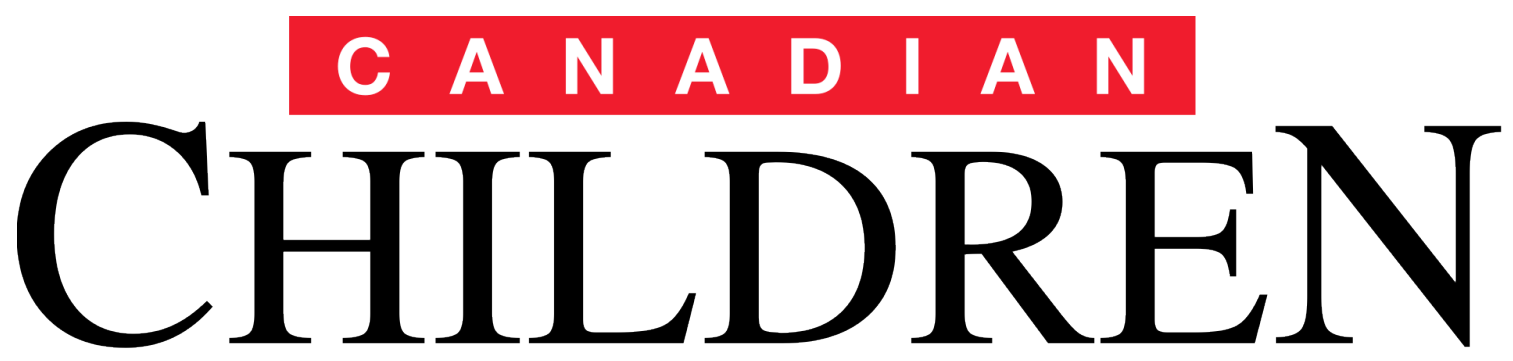

JOURNAL OF THE CANADIAN ASSOCIATION FOR YOUNG CHILDREN

\title{
Negotiating Status: The Impact of Union Contracts on the Professional Role of RECEs in Ontario's Full-Day Kindergarten Programs \\ By Romona Gananathan
}

\section{A N A D I A N}

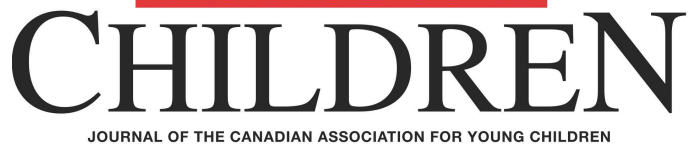

JOURNAL OF THE CANADIAN ASSOCIATION FOR YOUNG CHILDREN

Winter 2015/Hiver 2015

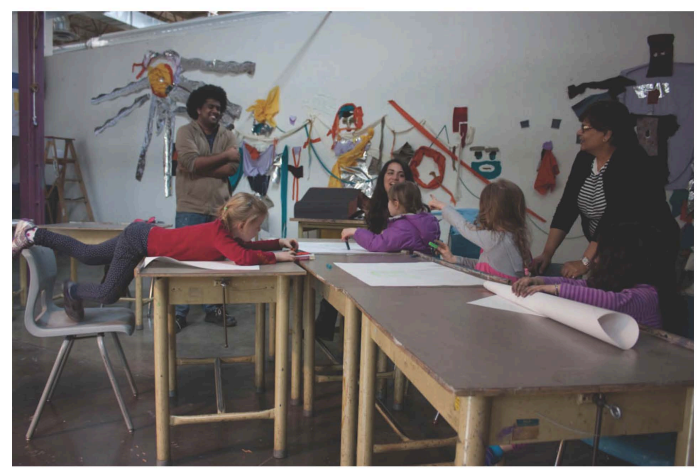

The Canadian Association
for Young Children
Editors:

Dr. Laurie Kocher, Douglas College, Coquitlam, British Columbia Dr. Veronica Pacini-Ketchabaw, University of Victoria, Victoria, British Columbia

Guest Editors, Special Issue: Professionalism in ECEC Dr. Rachel Langford, Dr. Jane Hewes, Sonya Hooper, and Monica Lysack

Publications Chairperson:

Dr. Iris Berger,

University of British Columbia,

Vancouver, British Columbia

Cover Photo:

Dr. Sylvia Kind

(C) 1996: The Canadian Association for Young Children ISSN: 0833-7519

Author Guidelines: visit www.cayc.ca

Published with support from the Social Sciences and Humanities Research Council of Canada

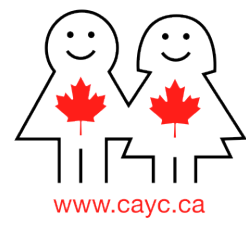




\title{
Canadian Children
}

\section{JOURNAL OF THE CANADIAN ASSOCIATION FOR YOUNG CHILDREN}

Volume 40 Number 12015 [pages 20 to 35]

www.cayc.ca

\section{Negotiating Status: The Impact of Union Contracts on the Professional Role of RECEs in Ontario's Full-Day Kindergarten Programs}

\section{by Romona Gananathan}

\begin{abstract}
Author's Bio
Romona Gananathan is a $\mathrm{PhD}$ candidate at the Ontario Institute for Studies in Education, University of Toronto, with a background in law and policy governance. She has been involved in the early childhood community as a researcher, director of nonprofit early childhood programs, union organizer, and board member. Her research interests are focused on the legal and policy perspectives of the labour implications in the integration of early learning and education programs. Email: romona.gananathan@gmail.com
\end{abstract}

\begin{abstract}
This paper analyzes three union contracts as a way to unpack the ways in which the professional role of the registered early childhood educator (RECE) in full-day kindergarten (FDK) programs in Ontario is recognized and constructed in policy texts. The paper examines what constitutes an "early learning professional" compared to a "teacher" or "educational assistant," and how the discourses of professionalism are constructed through policy texts to position the role of RECEs in FDK. Results from this study suggest that union contracts play an important role in shaping the new "professional" role and status of RECEs in FDK programs.
\end{abstract}




\section{Overview}

The professional role of RECEs is evolving through the integration of care and education through full-day kindergarten (FDK) programs across Canada. While unions have historically played an integral role in improving the wages and working conditions of RECEs in the childcare sector, integration of early learning into the education sector presents a new opportunity to raise the professional profile and working conditions of RECEs. This paper examines the union contracts of three major unions that represent the RECEs in FDK programs in Ontario, namely the Canadian Union of Public Employees (CUPE), the Ontario Secondary School Teachers' Federation (OSSTF), and the Elementary Teachers' Federation of Ontario (ETFO). Using a comparative text analysis approach, this paper examines how the program and policy intent articulated in Ontario's Education Act to establish professional early learning pedagogical teams has been realized through policy documents such as union contracts. In particular, the impact of union contracts on the new professional role and status of RECEs in the education sector is examined, including the material gains and potential losses realized by the RECEs in FDK based on their union contracts through wages, benefits, and working conditions. For example, while unionization can benefit RECEs, it is important to understand the differences in union approaches to negotiating RECE contracts and the ways in which these influences shape the role and status of RECEs in FDK programs. The findings in this paper can provide insight to stakeholders in other jurisdictions about union processes to ensure better professional recognition of RECEs through negotiated union contracts.

\section{Legislative Context}

Primary education has been a universal right in Ontario since 1844 under the Education Act, while explicit support for early childhood education and care was introduced much later under the1945 Day Nurseries Act and the 1971 Child and Family Services Act. Childcare programs were introduced to support increasing numbers of women moving into the workforce, to provide enrichment to children in need, and later to support dual-income families. These licensed child care programs were primarily staffed by RECEs and other support staff and for the most part were not represented by union contracts. As of 2007, RECEs in Ontario are now required to be registered with the College of Early Childhood Educators (Early Childhood Educators Act, Government of Ontario, 2007).

In 2010, Ontario's Education Act was amended to include changes related to the implementation of full-day kindergarten (Legislative Assembly of Ontario, 2010). One of these changes was the introduction of a team teaching model in the full-day early learning-kindergarten (FDELK) program, which placed a registered early childhood educator (RECE) and a certified teacher in the kindergarten classroom as professional partners with a "duty to cooperate" in designing and delivering a play-based full-day early learning program (Education Act, 1990, s. 264.1). This new model of pairing a

\section{Canadian Children}


teacher and an early childhood educator was the first of its kind in a Canadian jurisdiction. Prior to this change in legislation, kindergarten programs were under the purview of certified teachers and ancillary support staff.

Although RECEs have previously worked in the education sector, they have occupied support roles as educational assistants in classrooms have had no curriculum planning, assessment, or independent child supervision responsibilities. The recent legislative and policy changes to integrate care and education in Ontario's FDK program recognize the early child development knowledge and expertise of RECE professionals, as envisioned by Pascal (2009). RECEs in FDK programs are now required to plan and deliver curriculum together with the teacher, participate in assessments, supervise children (without the need for a teacher to be present in the classroom) and deliver a playbased curriculum (Ontario Ministry of Education, 2010b).

Elementary teachers in Ontario are legislated to belong to a teachers' union (Government of Ontario, Education Act, s. 277.4 [3]). However, the legislative changes made to the Education Act in 2010 were silent about which union would represent the new RECE early learning professional in FDK. As a result of this omission, education sector unions scrambled to organize the RECEs, resulting in them being represented by a variety of unions and professional associations across the province. Unlike elementary teachers, who are represented by one union (in either the Catholic or the public sector) and have one collective voice and bargaining power with similar wages and working conditions, RECEs in Ontario are left with a variety of union contracts and a patchwork of wages and working conditions. Some of these unions represent support staff, secondary school teachers and professional associations in the education sector, and may not fully appreciate the context of the RECEs' new professional role in FDK programs. As a result, the potential gains afforded through the Education Act amendment may have been eroded in terms of both role and status of RECEs as well as any material gains in wages and working conditions that might have occurred as a result of these increased roles and responsibilities.

\section{Union Representation in Full-Day Kindergarten}

In Ontario, there are two routes to representation by a union: voluntary recognition or certification of a bargaining unit (Government of Ontario, Labour Relations Act, ss. 7-15). Voluntary recognition is an informal process that allows employers to voluntarily recognize that a union represents a certain category of workers that may include incorporating a new job classification into an existing collective agreement. A more formal and sometimes lengthy process requires a union to apply for certification through the Ontario Labour Relations Board (OLRB) to represent a group of workers in a newly defined bargaining unit. Before a certificate of representation is issued, this process requires the union to show support from the group of employees by way of signed membership cards and winning a vote arranged by the OLRB.

\section{Canadian Children}


Based on the Education Act amendment, the new early learning professional role of RECEs in FDK affords the RECEs in FDK programs higher status as professional partners within the team. Unlike previous educational assistance roles that they occupied in the education sector that have no curriculum planning, assessment, or independent child supervision responsibilities, RECEs in FDK programs are required to plan and deliver curriculum together with the teacher, participate in assessments, supervise children (without the need for a teacher to be present in the classroom) and deliver a playbased curriculum (Ministry of Education, 2010-2011).

Despite the significant changes in responsibility for the new RECE role in FDK in Ontario, two large education sector unions, CUPE and OSSTF, entered into voluntary recognition agreements with many Ontario school boards, arguing that they already represented educational assistants with early childhood education qualifications in schools, and that the new RECE job category fell within the parameters of their existing collective agreements. They subsequently won the right to represent RECEs in full-day kindergarten. As a result, a majority of Ontario's 64 school boards took the voluntary recognition approach with respect to RECEs in FDK classrooms.

In contrast to the approach taken by CUPE and OSSTF, the union that represents Ontario's elementary school teachers seized the opportunity to expand its representation through the certification process. ETFO launched a large-scale campaign in 2010 to organize as many RECEs as possible in the education sector. The process entailed several legal challenges at the OLRB (see, for example, Elementary Teachers' Federation of Ontario v. York Region District School Board, Globe 24h Case Law, 2012) to determine whether the RECEs in question fell within an existing agreement or were an appropriate bargaining unit of their own. Interestingly, and despite ETFO's earlier political lobbying against introducing RECEs into the FDK classrooms as teaching partners (Elementary Teachers' Federation of Ontario, 2009), ETFO's organizing campaign was entitled "one union, one profession," implying that the RECEs and teachers should have equal recognition as early educators. ETFO president Sam Hammond strongly supported the RECEs joining the ETFO, stating,

Membership in the same union will have many advantages both for teachers and for ECEs: it will facilitate team building, professional learning, quicker problem solving and conflict resolution. A strong, united early learning team is better placed to resist pressure. ETFO understands elementary education and elementary educators. This federation is a natural choice for ECEs. Our ECE members will be equal partners in our federation. (Elementary Teachers' Federation of Ontario, 2010, p. 4).

Interestingly, a number of leaders within the early childhood sector and the Association of Early Childhood Educators of Ontario also endorsed ETFO as the most 
effective and professional union for the new school board RECEs. As a result of the campaign, ETFO was successful in organizing 10 of Ontario's 64 school boards and has won the right to represent RECEs as separate bargaining units in these workplaces. The differences in representation among the three educational unions presents an opportunity to analyse how a professional role and status is constructed through union contracts and to assess whether there is any material difference in the wages and working conditions in the three contracts.

\section{Content Analysis of Union Contracts}

Bredeson (2001) suggests that teacher unions have an inordinate amount of influence in schools. He argues that union contracts can provide an "important lens for examining organizational structures and dynamics" (Bredeson, 2001, p. 3). This paper undertakes a comparative content analysis of three union collective agreements as one lens for examining the organizational influences and dynamics that these unions bring to negotiating the new professional role and status of RECEs in FDK programs in Ontario. I explore how the language in the three union contracts reflects and constructs the importance that schools, administrators, and unions place on new professional RECE roles and analyze the extent to which the roles are explicitly recognized and in what ways the contract language determines wages, hours, preparation time, and other conditions of employment that could influence the RECEs' pedagogical practice in the newly designed team teaching model.

Union contract provisions are negotiated within the context of a variety of formal and informal processes, policies, and practices that can "confound and compound the contract's power to influence" (Bascia, 1994, p. 83). These could include the union's history, its relationship with its members, and the political influences that shape the negotiation of particular contract provisions, which in turn have a powerful impact on the working conditions and status of the union's members. This paper thus engages in content analysis of the union contracts within the context of a broader understanding of the discourses that have shaped the specific provisions articulated in the contracts and with a view to contextualizing the union agreements as historic artefacts, or an imperfect record of earlier (or current) issues and decisions. This content analysis forms part of a broader analysis of the legal and policy construction of the new early learning professional in Ontario, which investigates the labour policy implications of FDK implementation on the status and working conditions of RECEs in Ontario.

\section{RECE Wages and Working Conditions in FDK: A Comparison of Three Union Contracts}

The three union contracts reviewed for this paper reflect three large unions representing RECEs in full-day kindergarten in three Ontario school boards: 
- Toronto District School Board-CUPE Unit C Agreement and Related Documents

- Ottawa-Carleton District School Board-OSSTF District 25 Educational Support Professionals Agreement and Related Letters of Understanding

- Toronto Catholic District School Board-ETFO Agreement

To compare wages and working conditions, I identified major contractual provisions that form the basis of RECEs' compensation as well as non-compensationrelated items that contribute to working conditions in the workplace, as detailed in Table 1. In addition, I refer to and analyze addenda and memoranda relating to RECEs in FDK that were either agreements made after the ratification of the existing collective agreement or form part of the union contract with the employer.

Table 1: Comparison of specific provisions in the CUPE, OSSTF, and ETFO agreements.

\begin{tabular}{|c|c|c|c|}
\hline Contract Provision & CUPE & OSSTF & ETFO \\
\hline Scope of agreement & $\begin{array}{l}\text { Covers office, } \\
\text { clerical, secretarial, } \\
\text { technical staff, } \\
\text { educational } \\
\text { assistants, aquatic, } \\
\text { health care, food } \\
\text { services staff, } \\
\text { itinerant music } \\
\text { instructors, and } \\
\text { school support staff }\end{array}$ & $\begin{array}{l}\text { Covers all } \\
\text { professional } \\
\text { support staff }\end{array}$ & $\begin{array}{l}\text { Covers designated } \\
\text { ECEs in FDK as defined } \\
\text { by the Education Act }\end{array}$ \\
\hline Size of document & $\begin{array}{l}188 \text { pages (including } \\
\text { addenda) }\end{array}$ & $\begin{array}{l}85 \text { pages } \\
\text { (including } \\
\text { addenda of } 8 \\
\text { pages) }\end{array}$ & $\begin{array}{l}75 \text { pages (including } \\
\text { addenda) }\end{array}$ \\
\hline Union representation & $\begin{array}{l}80 \text { stewards from all } \\
\text { jobs, negotiation } \\
\text { committee of } 8 \\
\text { members get } 700 \\
\text { hours off with pay } \\
\text { for negotiations }\end{array}$ & $\begin{array}{l}5 \text { bargaining } \\
\text { committee reps, } 3 \\
\text { labour } \\
\text { management } \\
\text { committee reps, } 3 \\
\text { grievance } \\
\text { committee reps } \\
\text { with paid time off } \\
\text { for bargaining, } \\
\text { meetings, and } \\
\text { grievance } \\
\text { resolution }\end{array}$ & $\begin{array}{l}\text { Executive Committee } \\
\text { of ECEs and } 20 \text { days } \\
\text { leave with pay for } \\
\text { officials to conduct } \\
\text { union duties }\end{array}$ \\
\hline Number of times ECE is & 1 time in schedule of & None in collective & 279 times (designated \\
\hline
\end{tabular}

Canadian Children 


\begin{tabular}{|c|c|c|c|}
\hline Contract Provision & CUPE & OSSTF & ETFO \\
\hline $\begin{array}{l}\text { mentioned in the } \\
\text { agreement }\end{array}$ & job categories & $\begin{array}{l}\text { agreement; } 16 \\
\text { mentions of ECE in } \\
\text { letter of agreement }\end{array}$ & ECE or DECE) \\
\hline $\begin{array}{l}\text { Number of times the word } \\
\text { professional is used in the } \\
\text { agreement }\end{array}$ & $\begin{array}{l}19 \text { times, related to } \\
\text { PA or PD, } \\
\text { professional } \\
\text { librarian and } \\
\text { professionals or } \\
\text { paraprofessionals }\end{array}$ & $\begin{array}{l}49 \text { times, related } \\
\text { to professional } \\
\text { associations, } \\
\text { professional } \\
\text { growth, } \\
\text { professional } \\
\text { training, etc. }\end{array}$ & $\begin{array}{l}10 \text { times, related to } \\
\text { professional practice, } \\
\text { professional duties, } \\
\text { professional activity, } \\
\text { and professional } \\
\text { training }\end{array}$ \\
\hline Salary & $\begin{array}{l}\text { Refers to schedule A } \\
\text { but not included in } \\
\text { document }\end{array}$ & $\begin{array}{l}\text { Agreement for } \\
\text { board to post at a } \\
\text { starting salary of } \\
\$ 19.48 \text {, although } \\
\text { there was no } \\
\text { agreement on the } \\
\text { salary schedule }\end{array}$ & 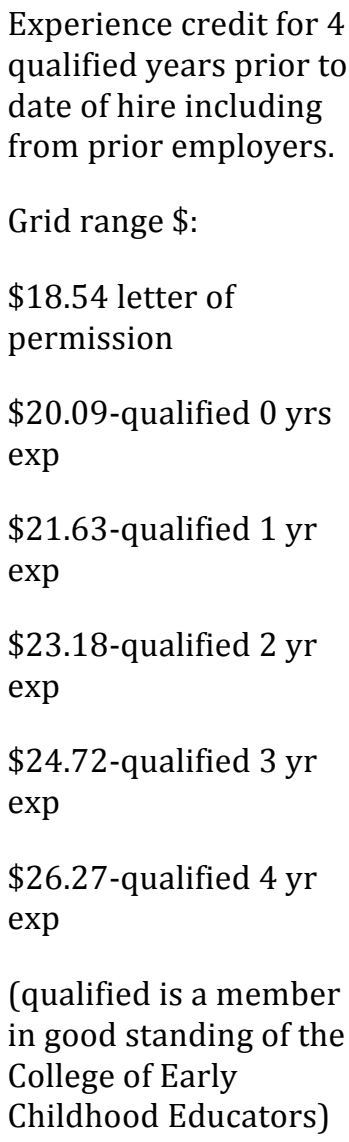 \\
\hline Hours & $\begin{array}{l}\text { ECE hours based on } \\
\text { program needs }\end{array}$ & $\begin{array}{l}\text { Between } 6.25 \text { and } \\
6.5 \text { hours per day } \\
\text { for core program. } \\
\text { Extended program } \\
\text { to be determined. }\end{array}$ & $\begin{array}{l}7 \text { hours per day /35 } \\
\text { hours per week }\end{array}$ \\
\hline Preparation time & $\mathrm{n} / \mathrm{a}$ & $\mathrm{n} / \mathrm{a}$ & $\begin{array}{l}30 \text { minutes each } \\
\text { instructional day or }\end{array}$ \\
\hline
\end{tabular}

Canadian Children 


\begin{tabular}{|c|c|c|c|}
\hline Contract Provision & CUPE & OSSTF & ETFO \\
\hline & & & $\begin{array}{l}150 \text { minutes for a } 5- \\
\text { day period, scheduled } \\
\text { in blocks no shorter } \\
\text { than } 15 \text { minutes }\end{array}$ \\
\hline Lunch break & $\begin{array}{l}\text { Unpaid lunch of } 30 \\
\text { minutes on shifts } \\
\text { over } 5.5 \text { hours }\end{array}$ & $\begin{array}{l}\text { 30-minute unpaid } \\
\text { lunch break }\end{array}$ & Unpaid 30 minutes \\
\hline Breaks & $\begin{array}{l}\text { Combined } \\
\text { rest/lunch of } 15 \\
\text { minutes per } 4 \text {-hour } \\
\text { day and } 2 \text { breaks of } \\
15 \text { minutes for days } \\
\text { over } 5.5 \text { hours }\end{array}$ & $\begin{array}{l}2 \text { paid } 15 \text {-minute } \\
\text { rest periods each } \\
\text { day or } 1 \text { rest } \\
\text { period of } 15 \\
\text { minutes for half } \\
\text { days }\end{array}$ & $\begin{array}{l}2 \text { paid breaks of } 15 \\
\text { minutes each day } \\
(\mathrm{am} / \mathrm{pm})\end{array}$ \\
\hline $\begin{array}{l}\text { Professional activity (PA) } \\
\text { or professional } \\
\text { development (PD) days }\end{array}$ & $\mathrm{n} / \mathrm{a}$ & $\begin{array}{l}\text { Union allowed to } \\
\text { offer training on } \\
\text { site on PD days- } \\
\text { time unpaid by } \\
\text { employer }\end{array}$ & 6 days/school year \\
\hline Comp/lieu time & $\begin{array}{l}\text { Overtime paid at } \\
1.5 \mathrm{x} \text { rate; lieu time } \\
\text { with approval }\end{array}$ & $\begin{array}{l}\text { ECEs are not } \\
\text { eligible for time off } \\
\text { in lieu; additional } \\
\text { hours assigned by } \\
\text { principal shall be } \\
\text { paid at straight } \\
\text { time }\end{array}$ & $\begin{array}{l}\text { If ECE works overtime, } \\
\text { as authorized by } \\
\text { principal }\end{array}$ \\
\hline Travel & .40 cents $/ \mathrm{km}$ & $\begin{array}{l}\text { Board-wide rate as } \\
\text { approved by the } \\
\text { supervisor }\end{array}$ & .45 cents $/ \mathrm{km}$ \\
\hline Training & $\begin{array}{l}\text { Employer shall } \\
\text { endeavour to } \\
\text { provide training } \\
\text { opportunities }\end{array}$ & $\begin{array}{l}\text { Paid time off and } \\
\text { cost of training for } \\
\text { required courses } \\
\text { to upgrade } \\
\text { qualifications }\end{array}$ & \\
\hline Pension plan & $\begin{array}{l}\text { OMERS or teachers' } \\
\text { pension plan if } \\
\text { qualified }\end{array}$ & $\begin{array}{l}\text { OMERS or OTIP if } \\
10 \text { or more month } \\
\text { employees }\end{array}$ & $\begin{array}{l}\text { OMERS or OTPP (for } \\
\text { DECEs with teaching } \\
\text { credentials) }\end{array}$ \\
\hline Statutory holidays & $\begin{array}{l}8 \text { days, including } \\
\text { New Years, Family } \\
\text { Day, Good Friday, } \\
\text { Easter Monday, }\end{array}$ & $\begin{array}{l}11 \text { days including } \\
\text { Easter Monday, } \\
\text { Canada Day, and } \\
\text { August civic }\end{array}$ & $\begin{array}{l}11 \text { days, including } \\
\text { Easter Monday + half } \\
\text { days before Christmas }\end{array}$ \\
\hline
\end{tabular}

Canadian Children 


\begin{tabular}{|c|c|c|c|}
\hline Contract Provision & CUPE & OSSTF & ETFO \\
\hline & $\begin{array}{l}\text { Victoria Day, } \\
\text { Thanksgiving, } \\
\text { Christmas, and } \\
\text { Boxing Day }\end{array}$ & holiday & and New Years \\
\hline Vacation & $\begin{array}{l}11 \text { days }- \text { less than } 1 \\
\text { year } \\
15 \text { days }-1 \text { to } 9 \text { yrs } \\
20 \text { days }-9 \text { to } 16 \text { yrs } \\
25 \text { days }-17 \text { to } 22 \\
\text { yrs }\end{array}$ & 15 working days & $\begin{array}{l}15 \text { days }- \text { less than } 1 \text { yr } \\
15 \text { days }-1 \text { to } 9 \text { yrs } \\
20 \text { days }-9 \text { to } 16 \text { yrs } \\
25 \text { days }-17 \text { yrs }\end{array}$ \\
\hline Benefit plan & $\begin{array}{l}\text { Health, dental, long- } \\
\text { term disability, life } \\
\text { insurance up to } \\
\$ 30,000\end{array}$ & $\begin{array}{l}\text { Health, dental, } \\
\text { long-term } \\
\text { disability, life } \\
\text { insurance up to } \\
\$ 45,000\end{array}$ & $\begin{array}{l}\text { Register after } 3 \text { months } \\
\text { of at least } 14 \\
\text { hrs/week; employer } \\
\text { pays } 100 \% \text { of } \\
\text { premium, health, vision } \\
\text { care- } \$ 350 / 2 \text { years, } \\
\text { orthopedic } \$ 900 / y r \text {, } \\
\text { life ins of } 3 x \text { annual } \\
\text { salary }\end{array}$ \\
\hline Seniority & $\begin{array}{l}\text { Seniority applies- } \\
30 \text { days notice to be } \\
\text { deemed surplus }\end{array}$ & $\begin{array}{l}\text { First consideration } \\
\text { for initial } \\
\text { vacancies will be } \\
\text { given to qualified } \\
\text { EA bargaining unit } \\
\text { members or other } \\
\text { OSSTF members; } \\
\text { seniority carried } \\
\text { forward }\end{array}$ & $\begin{array}{l}\text { Date of hire, layoff only } \\
\text { at the end of the school } \\
\text { year, on recall list for } 2 \\
\text { years }\end{array}$ \\
\hline Sick leave & $\begin{array}{l}\text { Eligible after } 15 \\
\text { hours/week up to } 24 \\
\text { days/yr prorated } \\
\text { based on } 12 \text { months }\end{array}$ & $\begin{array}{l}2 \text { days per month } \\
\text { prorated, to a } \\
\text { maximum } \\
\text { entitlement of } 340 \\
\text { sick leave credits }\end{array}$ & $\begin{array}{l}\text { Accumulated sick leave } \\
2 \text { calendar days per } \\
\text { month }\end{array}$ \\
\hline Other leaves & $\begin{array}{l}\text { General, political } \\
\text { activity, pregnancy, } \\
\text { infant/childcare } \\
\text { leave of } 1 \text { additional } \\
\text { year, family medical } \\
\text { leave }\end{array}$ & $\begin{array}{l}\text { No leaves of } \\
\text { absence with } \\
\text { pay-article } 19.09 \\
\text { does not apply to } \\
\text { ECEs }\end{array}$ & $\begin{array}{l}\text { Bereavement } 5 \text { days, } \\
\text { personal leave of } \\
\text { absence of up to } 1 \text { year, } \\
\text { jury duty, court } \\
\text { appearance, urgent } \\
\text { personal business, } \\
\text { family medical, } \\
\text { compassionate leave, }\end{array}$ \\
\hline
\end{tabular}

Canadian Children 


\begin{tabular}{|l|c|c|c|}
\hline Contract Provision & CUPE & OSSTF & ETFO \\
\hline & & & pregnancy/adoption \\
\hline
\end{tabular}

\section{CUPE Contract}

CUPE's collective agreement is the most extensive of the three contracts, covering a variety of clerical, technical, and educational support staff in one 188-page document. The RECEs in FDK were included in the existing collecting agreement through voluntary recognition by the Toronto District School Board because educational assistants with ECE qualifications were already represented by CUPE in this workplace. Remarkably, "ECE" is only mentioned once in the whole document in the schedule of job categories and there have been no attempts made to differentiate between the new professional role of RECEs in FDK compared to the educational assistant roles previously represented by the union. The term "professional" is used in relation to training and development in a general sense. Interestingly, this is the only one of the three contracts that uses the term "paraprofessionals." This could be attributed to the expertise of this particular union in representing paraprofessionals and support staff in the education sector.

Notable in this contract is the fact that RECEs are considered hourly employees whose hours are based on program needs. This allows for RECEs to be assigned split shifts and to be laid off in the middle of the school year. The fact that this contract offers only eight statutory holidays to its members - even though there is a minimum of nine statutory holidays a year in Ontario under employment standards legislation that generally applies to non-unionized staff - is significant. Presumably, the ninth holiday falls within the summer months and is not included in this contract, which may be the result of the temporary nature of RECEs' employment. Regardless, because of the scope of this contract and the various job categories it covers, it appears that the inclusion of the new professional role of RECEs in FDK has had little impact to elevate the status of RECEs covered by the contract, including those previously in educational assistant roles.

\section{OSSTF Contract}

OSSTF was granted a voluntary recognition agreement with the Ottawa-Carleton School District board because they represented educational assistants with ECE qualifications prior to the FDK implementation. OSSTF is a union that largely represents high school teachers, but it also represents a significant number of support staff in elementary schools. The language in this contract reflects this mix of professional and support roles throughout, for example, in the use of the terms "professional growth" and "professional associations" alongside "professional training." Although the OSSTF

\section{Canadian Children}


contract covers a large group of educational support professionals, it has a special letter of agreement that specifically addresses RECEs in FDK programs.

RECEs are considered hourly staff with a 6.25 or 6.5 -hour core day not including an unpaid lunch, which leaves RECEs open to being assigned split shifts to cover both the early morning and after-school periods of each day, particularly in the extended day program. At the same time, RECEs are not entitled to lieu time, and they are required to be paid "straight time pay" for any additional work time that is scheduled by the principal. It is unclear whether this provision would extend to overtime hours as defined under employment standards (normally hours over 44 are paid at 1.5 times the regular rate). In this contract, the RECE letter of agreement does not allow for any leaves of absence. It is unclear whether this has changed in subsequent agreements with the employer. Similarly, the RECEs are characterized as hourly paid employees rather than full-time permanent contract staff with more job security, which leaves the door open to shorter contracts with no express provisions that layoffs can only occur at the end of the school year.

\section{ETFO Contract}

ETFO won the right to represent the RECEs in FDK through certification. As a result, the ETFO contract covers a dedicated bargaining unit of RECEs, referred to as designated early childhood educators (DECEs) as described in the Education Act amendments. It is not surprising that the term DECE is mentioned 279 times throughout the contract. While the term "professional" was only used ten times in the contract, there appears to be a tacit acknowledgment throughout the agreement that the discussion is completely centred on professionals. For example, the term "professional" is used to describe the professional practice and professional duties of the DECEs and is not just related to professional activity days and professional training that are common to professionals in other agreements. In addition, there is detailed language in the ETFO agreement about the specific role of DECEs in the early learning program, including discussion about functioning in an early learning team teaching environment.

Importantly, this contract ensures that the DECE positions are considered fulltime ten-month contracts, and the DECEs are given three weeks' vacation over the December and March breaks. As a result, the contract ensures that DECEs can only be laid off at the end of each school year, which characterizes their employment as permanent contract staff, with seniority and right of first refusal to return to the same job the following year. It also prevents DECEs from having to apply for EI benefits over the December and March breaks. Sick time, benefits, pensions, and time off in lieu are all modelled after the teachers' collective agreements. Although DECE salaries are lower than the teachers', they are determined by a grid that recognizes prior experience, not only with the same employer, but also from previous employers both in and outside the education sector. This is the only contract that allows for paid time for DECEs on

\section{Canadian Children}


professional activity days, a clause that allows DECEs to participate alongside their teacher partners in board-sponsored professional development with pay. Also significant is the fact that this is the only contract that provides for 30 minutes of preparation time each instructional day, or 150 minutes in a five-day period. Although teachers receive 240 minutes of preparation time each week in comparison, this is a good starting point for DECEs; it recognizes their new role in planning curriculum, and it sets the tone for increased time in future negotiations. Overall, this contract appears to recognize the newly elevated status of RECEs in the FDK program as teaching partners in the classroom.

\section{Discussion: The Influence of Union Contracts on the Role and Status of RECEs}

Implementing Pascal's (2009) vision of a universally accessible publicly funded early education system shifts the provision of early care and education into the public education sector. This shift to a public system ostensibly creates better wages and working conditions for the RECE and elevates their professional role within the education sector in these new professional positions, which include increased responsibilities such as planning and implementing play-based curriculum alongside their teacher partners. In support of this fundamental shift, the Ontario Ministry of Education established a new Early Learning Division with an early learning mandate that includes child care and early education.

While these policy changes have the potential to elevate the status of RECEs in the education sector, analysis of these three union contracts indicates that the historical construction of RECEs as care providers rather than early educators impacted the existing contracts. For example, contracts with unions that formerly represented RECEs in support positions within the education sector have continued to reflect the new professional role in similarly constructed positions, while unions that did not previously represent RECEs in this support capacity have moved from characterizing the new roles as care providers toward a more complex early learning professional status within the teaching team in FDK programs. CUPE and OSSTF contracts reflect no changes to the new role of RECEs as early education professionals with teaching responsibilities in FDK. In fact, these union contracts group all RECE jobs, including educational assistants and childcare workers, under one job category regardless of the role they occupy as support staff in schools or in their new role as teaching partners in the FDK program.

There are a number of challenges outlined in the RECE contracts that contribute to the precarious nature of RECEs' status as professionals. Unlike teachers, who are guaranteed a full year salary, vacation plans, and professional development time and funding, RECE contracts are characterized by hourly salaries, less job security, and a potential for split shifts. For example, they are the only contracts that characterize RECEs in FDK programs in Ontario as hourly paid staff with less job security and the potential 
for split shifts. These contracts also include provisions that may erode basic employment standards rights, such as statutory holidays or overtime pay, given that they sometimes reflect fewer entitlements than legislated as minimum employment standards. Interestingly, the CUPE and OSSTF contracts also address the issue of travel time between locations independent of the unpaid lunch break, indicating that RECEs may be assigned to more than one work location each day. This also contributes to a more precarious job arrangement for RECEs who have to juggle split shifts and different classrooms at multiple school locations and negotiate relationships with teaching partners, supervising principals, children, and families in these different locations. Clearly this arrangement does not provide the time or supports required for RECEs to function in the classroom as a professional partner in the program. Given the large numbers of staff covered by these collective agreements and the range of job categories they reflect, it would be difficult for a subset of this group, such as RECEs in the FDK programs, to put forward any specific provisions related to their role or status in the program as part of future contract negotiations.

In contrast, ETFO's collective agreement represents only RECEs in the FDK program and recognizes the professional status of RECEs in FDK through specific contract language. This is the only union contract that characterizes RECEs as full time 10-month contract employees with no mid year layoffs, no split shifts and no erosion of basic employment standards. This is also the only union contract to recognize the professional role of RECEs as early educators with curriculum delivery expectations through the express provision for planning time. ETFO's contract also affords RECEs more access to paid training and more paid time off for union-related activities.

While CUPE and OSSTF limit seniority to the current job, ETFO managed to include prior experience from other employers as a creative proxy for seniority, and allows RECEs transferring into the education sector from the childcare sector to be compensated for their prior experience. This allows RECEs to be compensated in a way that recognizes their prior professional experience outside the education sector and improves their overall recognition and status in the education sector.

Although there is significant variation in how RECEs are positioned within union contracts, a number of provisions seem to level the playing field between CUPE, OSSTF, and ETFO, including access to pensions, unpaid lunches, paid breaks, vacation pay of three weeks to start and deferred salary plans. Although explicit salary information was not included in all the contracts, the Ontario government legislated the minimum wage for RECEs in FDK as starting at \$19.68 in year 1 and \$20.05 in year 2 (Ministry of Education, 2010a). This legislative provision made a significant difference in wages for RECEs in FDK programs in the education sector, regardless of the union they are represented by. While individual union contracts can provide for recognition of seniority or prior experience, they apply to specific groups of RECEs. Given the number of RECEs

\section{Canadian Children}


employed in the FDK programs in Ontario, the provincially legislated minimum pay for RECEs in FDK has been an effective way of improving the wages of RECEs across Ontario and recognizing the new professional role that RECEs play in FDK.

\section{Conclusion: Professional Recognition of RECEs in FDK}

The historic dichotomy between the care and education of young children has been well documented (Gananathan, 2011; Irvine, Kerridge, McPhee, \& Freeman, 2002; Wood, 2004) suggest that there are many barriers to interprofessional collaboration, including legal decisions that characterize power differentials between team members, and differences in professional value systems, professional organizations, registration requirements, professional training, and professional identity. Wood (2004) argues that while there has been a schism between care and education settings in the past, a contemporary consensus has emerged on the concept of "educare," which combines both elements.

While the implementation of FDK attempts to level the playing field between teachers and RECEs as early education professionals in Ontario (Ministry of Education, 2010b; Pascal, 2009), the failure to legislate RECEs as professional early educators to belong to teacher unions alongside their pedagogical partners sets up RECEs to negotiate the contested terrain of their work. It perpetuates the age-old rift between care and education and undermines the policy intent of integrating care and education in Ontario's FDK teaching teams. Other jurisdictions facing similar challenges in Canada, such as the Atlantic provinces, have embraced creative alternatives to develop stronger links between the two professionals, such as training for grandparented RECEs and teachers in order to establish one early learning professional (Moss \& Bennett, 2006), regardless of whether they were trained as teachers or RECEs. Ontario's reticence to recognize the professional status of RECEs in FDK through stronger labour-related legislative provisions is a lost opportunity to do the same.

As we have seen, unions can play a critical role in how RECEs' new professional role is redrawn in the "educare" context and how the RECEs' role and status as early development specialists get recognized. Regardless of which union represents the RECEs in FDK, there needs to be stronger language in union contracts to reflect RECEs' team teaching role, their elevated responsibilities of curriculum planning and delivery, and their new professional role in FDK programs. Some key considerations for unions include addressing the need for adequate paid time for curriculum planning, full-time stable employment with comparable benefits to provide consistency in the program, and greater opportunities for professional training, such as additional qualification (AQ) courses in assessment, literacy, and numeracy with related pay increases (similar to what teachers receive for completing kindergarten AQ courses) in order to build stronger collaborations with kindergarten teachers. 
Union contracts need to recognize the differences between RECEs in care roles (such as educational assistants who have a support role in the classroom) and RECEs in FDK programs (who have program planning, assessment, and curriculum delivery expectations) through express language that describes RECEs in FDK as early education professionals. For example, RECEs in FDK should be listed as a separate professional job class in union contracts. Given the large number of RECEs represented by CUPE and OSSTF through voluntary recognition agreements across the province, the potential impact on the role and status of RECEs is substantial if the role continues to be characterized in a support capacity. It is time for unions to step up to the plate and implement contract language that reflects the team teaching model and policy intent behind the Education Act amendments. As discussed previously, governments play a key role in legislating minimum pay scales to reflect the professional roles of RECEs in FDK programs and ensuring recognition for their professional skills and expertise. It would be beneficial for governments to strengthen the role of RECEs as teaching partners in the FDK program and to consider ways to improve the team teaching relationship and working conditions of both team members. This could be achieved through skills training for RECEs and teachers with a view to levelling the playing field, and revisiting the notion of legislating RECEs in the FDK program to belong to a teachers' union.

\section{References}

Bascia, N. (1994). Excerpt on reading collective agreements: Unions in teachers' professional lives. New York, NY: Teachers' College Press.

Bredeson, P. (2001). Negotiated learning: Union contracts and teacher professional development. Education Policy Analysis Archives, 9(26), 1-24.

Elementary Teachers' Federation of Ontario. (2009). A qualified teacher is key to success in kindergarten: Response to the report of the special learning advisor. Toronto, ON: Author.

Elementary Teachers' Federation of Ontario. (2010). ETFO and early childhood educators: A great fit. ETFO Voice, 13(1). Retrieved from: http://etfovoice.ca/back-issues/2010/V13N1_OCT 10.pdf

Gananathan, R. (2011). Implications of full-day kindergarten program policy on early childhood pedagogy and practice. International Journal of Child Care and Education Policy, 5(2), 31-43.

Globe 24h Case Law. (2012). CanLII 47356 (ON LRB). Elementary Teachers' Federation of Ontario v. York Region District School Board. Retrieved from: http://caselaw.canada.globe24h.com/0/0/ontario/ontario-labour-relationsboard/2012/08/14/elementary-teachers-federation-of-ontario-v-york-regiondistrict-school-board-2012-47356-on-lrb.shtml

\section{Canadian Children}


Government of Ontario. (1990). Education Act, RSO 1990, c.E.2. Retrieved from: https://www.canlii.org/en/on/laws/stat/rso-1990-c-e2/latest/rso-1990-c-e2.html

Government of Ontario. (1995). Labour Relations Act., SO 1995, c1, Sch A. Retrieved from: https://www.canlii.org/en/on/laws/stat/so-1995-c-1-sch-a/latest/so-1995-c1-sch-a.html

Government of Ontario. (2007). Early Childhood Educators Act, SO 2007, c 7, Sch 8. Retrieved from: https://www.canlii.org/en/on/laws/stat/so-2007-c-7-sch8/latest/so-2007-c-7-sch-8.html

Irvine, R., Kerridge, I., McPhee, J. \& Freeman, S. (2002). Interprofessionalism and ethics: Consensus or clash of cultures? Journal of Interprofessional Care, 16(3), 200-210.

Legislative Assembly of Ontario. (2010). Bill 242, Full-Day Early Learning Statute Law Amendment Act. Retrieved from: http://www.ontla.on.ca/web/bills/bills_detail.do?locale=en\&Intranet=\&BillID $=22$ $\underline{69}$

Moss, P. \& Bennett, J. (2006). Toward a new pedagogical meeting place? Bringing early childhood into the education system. Briefing paper for a Nuffield Educational Seminar. London, UK: Nuffield Foundation.

Ontario Ministry of Education. (2010a). Memorandum on legislative changes under Bill 242-EL6. Retrieved from: http://cal2.edu.gov.on.ca/may2010/2010EL6_Bill242.pdf

Ontario Ministry of Education. (2010b). The full-day early learning kindergarten program. Retrieved from: http://www.edu.gov.on.ca/eng/curriculum/elementary/kindergarten.html

Pascal, C. (2009). With our best future in mind: Implementing early learning in Ontario. Toronto, ON: Queen's Printer.

Wood, E. (2004). Developing a pedagogy of play. In A. Anning, J. Cullen, \& M. Fleer (Eds.), Early childhood education: Society and culture (pp. 19-30). London, UK: SAGE. 


\section{In this issue:}

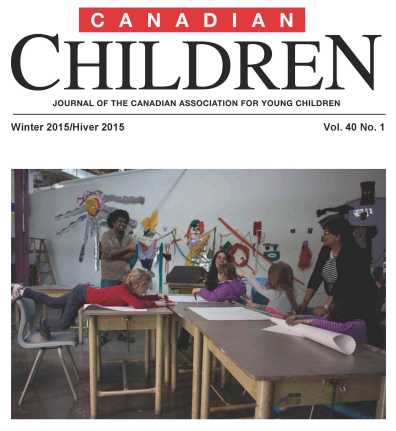

From the Editors' Desk Special Issue: Professionalism in ECEC Guest Editors: Dr. Rachel Langford, Dr. Jane Hewes, Sonya Hooper, and Monica Lysack

Beyond Professionalism: Interrogating the Idea and the Ideals by Randa Khattar and Karyn Callaghan

Negotiating Status: The Impact of Union Contracts on the Professional Role of RECEs in Ontario's Full-Day Kindergarten Program by Romona Gananatham

The Glass Ceiling Effect: Mediating Influences on Early Years Educators' Sense of Professionalism by Stefanie Tukonic and Debra Harwood

Enhancing Professionalism and Quality Through Director Training and Collegial Mentoring by Glory Ressler, Gillian Doherty, Tammy McCormick Ferguson, and Jonathan Lomotey

Authoring Professional Identities: Immigrant and Refugee Women's Experiences in an Early Childhood Teacher Education Program by Christine Massing

ECEs as Childcare Advocates: Examining the Scope of Childcare Advocacy Carried out by ECEs from the Perspective of Childcare Movement Actors in Ontario and Manitoba by Lyndsay Macdonald, Brooke Richardson, and Rachel Langford

From Child-Minders to Professionals: Insights From an Action Research Project on Prince Edward Island by Anna Baldacchino, Ray Doiron, Martha Gabriel, Alaina Roach O'Keefe, and Jessica McKenna

Pedagogical Narrations and Leadership in Early Childhood Education as Thinking in Moments of Not Knowing by Iris Berger

Find other articles from this issue at www.cayc.ca 